\title{
A clinical study on skin cancer in Indonesian patients
}

\author{
Mochtar Hamzah ${ }^{1}$, Masamitsu Ichihashi ${ }^{2},{\text { Herman } \text { Cipto }^{1} \text {, Evert DC Poetiray }}^{3}$, Arman Mukhtar ${ }^{3}$, Mpu Kanoko ${ }^{4}$, \\ Achmad Tjarta ${ }^{4}$, Masato Ueda ${ }^{2}$, Santoso Cornain ${ }^{4}$, Setyawati Budiningsih ${ }^{5}$, Joedo Prihartono ${ }^{5}$, Yoshiyuki Ohno ${ }^{6}$, \\ Nobuo Munakata ${ }^{7}$
}

\begin{abstract}
Abstrak
Telah dilaku'ian penelitian kasus kontrol mengenai aspek klinis kanker kulit sejak Januari 1996 sampai dengan Maret 1999 di Rumah Sakit Umum Pusat Nasional Dr. Cipto Mangunkusumo (RSUPNCM) Jakarta yang merupakan penelitian bersama antara Indonesic dan Jepang. Selama ini telah diteliti 139 pasien kanker kulit dan ditemukan 91 (65,5\%) kasus karsinoma sel basal (KSB), 32 (23,0 \%) kasus karsinoma sel skuamosa (KSS), II (7,9 \%) kasus melanoma maligna (MM), sedangkan lentigo maligna, keratosis solaris, karsinoma basoskuamosa dan penyakit Bowen masing-masing 1 pasien. Semua kasus dikumpulkan dari poliklinik Penyakit Kulit dan Kelamin dan poliklinik Bedah sub bagian Onkologi RSCM Jakarta. Dari 91 kasus KSB, 53 (58,2\%) adalah wanita dan 38 (41,8 \%) adalah pria. Umur mereka berkisar antara 32-87 tahun (rata-rata 59,4 12,2 tahun). KSS yang terdapat pada 32 kasus terdiri atas $13(40.6 \%$ wanita dan $19(59,4 \%$ ) pria. Umur mereka berkisar antara 24-85 tahun (rata-rata 57,8 $\pm 15,5$ tahun). MM terdapat pada 11 kasus dan terdiri atas $8(72,7 \%)$ wanita dan $3(27,3 \%)$ pria. Umur mereka berkisar antara 30-80 tahun (rata-rata 51,6 $\pm 16,2$ tahun). Mengenai lokalisasi tumor pada daerah terpajan matahari atau tidak, aidapatkan masing-masing: KSB 88 (96,7 \%) dari 91 kasus, KSS $12(37,5 \%)$ di daerah terpajan, $20(62,5 \%)$ di daerah tidak terpajan. Diantara MM $3(27,3 \%)$ pada daerah terpajan, 8 $(72,7 \%)$ pada daerah tidak terpajan. Rasio KSB terhadap KSS ialah $83: 30=2,8: 1$
\end{abstract}

\begin{abstract}
A case control study has been performed since January 1996 until March 1999, concerning the clinical aspects of skin cancer at Dr. Cipto Mangunkusumo National Central General Hospital (RSUPNCM) Jakarta, as a joint research between Indonesia and Japan. So far, we have studied 139 skin cancer cases ana found 91 (65.5\%) basal cell carcinoma (BCC), $32(23.0 \%)$ squamous cell carcinoma (SCC), $11(7.9 \%)$ malignant melanoma (MM), while lentigo maligna, solar keratosis, basosquamous carcinoma and Bowen's disease in 1 patient, respectively. All the cases were obtained from the policlinic of the Department of Dermatology and the Department of Surgery, Oncology subdivision, Dr. Cipto Mangunkusumo National Central General Hospital, Jakarta. From the 91 BCC cases, 53 $(58.2 \%)$ were females and $38(41.8 \%)$ were males. Their age range between $32-87$ years old (mean $=59.4 \pm 12.2$ yrs). The sites of $B C C$ were almost all on the face, except for two cases on the back and hand. SCC found in 32 cases consisted of 13 (40.6 \%) females and $19(59.4 \%$ males. Their age range between $24-85$ years old (mean $=57.8 \pm 15.5$ yrs). MM occurred in 11 patients, consisting of $8(72.7 \%)$ females and $3(27.3 \%)$ males. The age ranged between $30-80$ years (mean $=51.6 \pm 16.2$ yrs). They were also evaluated against localization in sun exposed and non-sun exposed part of the skin. The majority of BCC, i.e., 88 (96.7\%) of 91 was located at sun exposed area. Among SCC cases $12(37.5 \%)$ occurred on sun exposed area and $20(62.5 \%)$ on non-sun exposed area. Among $M M$ cases $3(27,3 \%)$ occurred on sun exposed area and $8(72.7 \%)$ on non- sun exposed area. The ratio of BCC to SCC is $91: 32=$ 2.8:1.
\end{abstract}

Keywords: Basal cell carcinoma, squamous cell carcinoma, skin typing

Department of Dermatology. Faculty of Medicine, University of Indonesia, Jakarta 10430. Indonesia

2 Department of Dermatology, Kobe University School of Medicine, Kobe 650-0017, Japan

3 Department of Surgery, Faculty of Medicine, University of Indonesia, Jakarta 10430, Indonesia

4 Department of Anatomic Pathology, Faculty of Medicine, University of Indonesia, Jakarta 10430, indonesia

5 Department of Community Medicine, Faculty of Medicine, University of Indonesia, Jakarta 10320, Indonesia

6 Department of Preventive Medicine, Nagoya University School of Medicine, Nagoya 466-8550, Japan

7 Radiobiology Division, National Cancer Center Research Institute, Tokyo 104-0045, Japan
Skin cancer especially non-melanoma skin cancer (NMSC) is the most common cancer in Indonesia, as well as in other places in the world. 'The Indonesian National Center for Pathology-based Cancer Registry in 1992 reported that skin cancer ranked the first in males and the fourth in females.

The marked rise in incidence of squmous cell carcinoma has been noticed in United States ${ }^{3,4}$ and other countries ${ }^{5,6}$ since 1970 through 1980 , which was consistent with the increase of basal cell carcinoma and malignant melanoma. General concern 
was due to both the increasing incidence and the mortality. ${ }^{3,4}$

Solar ultraviolet exposure has been considered as the important factor for the development of nonmelanoma skin cancer for quite a long time. Such an effect has been also observed recently although the association might be more complex.

The development of squamous cell carcinoma has been implicated in a prospective study ${ }^{7}$ as well.

Higher incidence of non-melanoma skin cancers among white people has been reported to be related to the latitude closer to equator. ${ }^{8}$

It will be interesting to study such relationship among Indonesian population living at and around the equatorial belt.

A case-control study was conducted in 1995 in Dr. Cipto Mangunkusumo National Center General Hospital (RSUPN-CM) Jakarta, as a joint research between Indonesia and Japan.

The aim of this study is to find characteristics of the various clinical aspects of each type of skin cancer in Indonesian patients.

\section{MATERLALS AND METHODS}

All cases of skin cancer were obtained from the policlinic of the Department of Dermatovenereology and the policlinic of Department of Surgery, Oncology subdivision at Dr. Cipto Mangunkusumo Hospital, Jakarta. The study included patients who came for consultation at both policlinics since January 1996 until March 1999. Age, sex, nationality, site, duration of illness, type of tumor, size and localization were recorded from each patient. Patients were divided into sex and age group in decades. The sites of tumor were grouped into sun-exposed area, i.e. neck, hand and forearm and the non sun-exposed area, i.e. trunk, soles, back and buttock.

\section{RESULTS}

In this study, we evaluated 139 skin cancer cases. The most frequent skin cancer was BCC (91 cases, 65.5 $\%$ ) and SCC was the second (32 cases, $23.0 \%$ ). We saw $11(7.9 \%)$ cases of malignant melanoma, 2 cases of lentigo maligna (precursor to $\mathrm{MM}$ ), 1 solar keratosis (precursor of SCC), basosquamous cell carcinoma and Bowen's disease (precursor of SCC), respeciively.

Among the $91 \mathrm{BCC}$ cases, 53 (58.2\%) were females and $38(41.8 \%)$ were males. The age ranged from 32 to 87 years old $($ mean $=59.4 \pm 12.2 \mathrm{yrs}$ ). See Table 1 . The most frequent site affected was the face, especially the cheek and the nose. The total number of SCC was 32 cases, consisting of 13 females (40.6\%) and 19 males $(59.4 \%)$. The age ranged between 24 85 years old (mean $=57.8 \pm 15.5 \mathrm{yrs}$ ).

The distribution of all skin cancers, BCC and SCC according age groups are depicted in Figures 1, 2 and 3 respectively.

Table 1. Distribution of Non-melanoma (BCC, SCC) and MM according to sex of patients

\begin{tabular}{|c|c|c|c|c|c|c|c|}
\hline \multirow{3}{*}{ Sex } & \multicolumn{4}{|c|}{ Non-melanoma } & \multirow{2}{*}{\multicolumn{2}{|c|}{ Melanoma }} & \multirow{3}{*}{ Total } \\
\hline & \multicolumn{2}{|c|}{$\mathrm{BCC}$} & \multicolumn{2}{|c|}{ SCC } & & & \\
\hline & $\mathrm{n}$ & $\%$ & $\mathrm{n}$ & $\%$ & $\mathrm{n}$ & $\%$ & \\
\hline Female & 53 & 58.2 & 13 & 40.6 & 8 & 72.7 & \\
\hline Male & 38 & 41.8 & 19 & 59.6 & 2 & 27.3 & \\
\hline Total & 91 & (100) & 32 & $(100)$ & 11 & $(100)$ & 139 \\
\hline
\end{tabular}

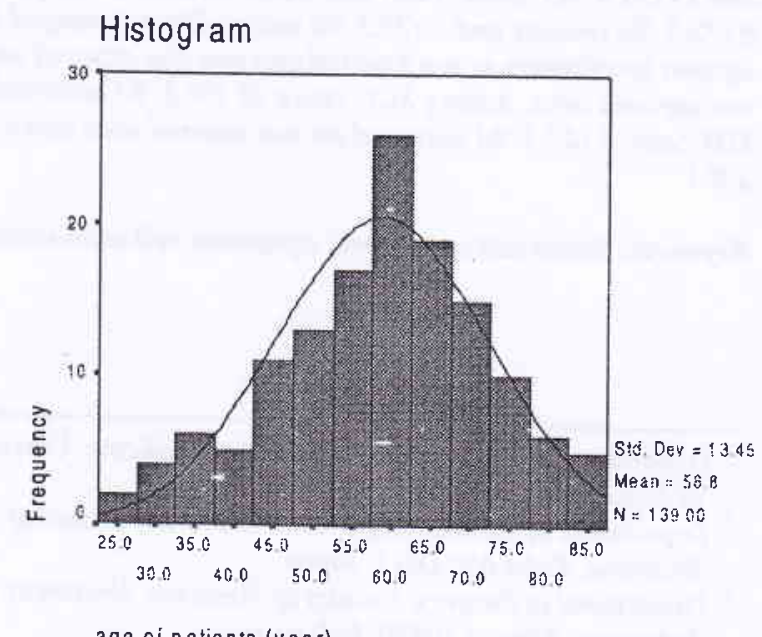

age oi patients (year)

Figure 1. Histogram of all skin cancers according to age groups 


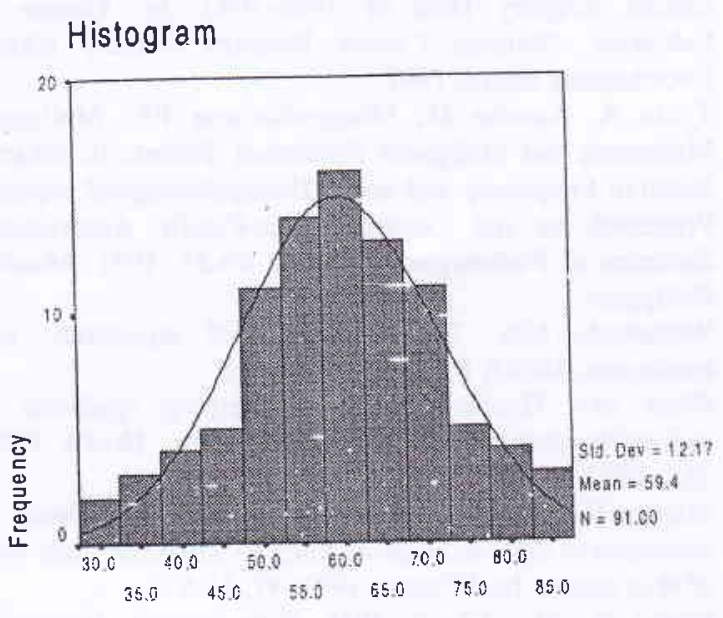

age of patients (year)

Figure 2. Histogram of $B C C$ according to age groups

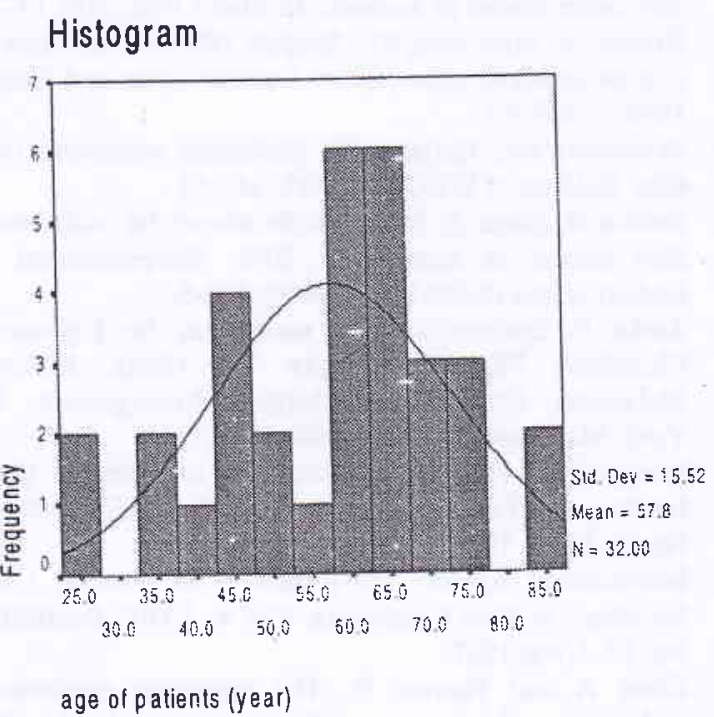

Figure 3. Histogram of SCC according to age groups

The duration of the tumor ranged from 6 months to 20 years for BCC (mean $=4.40 \mathrm{yrs}$ ), whereas for $\mathrm{SCC}$ and $\mathrm{MM}$ from 1 month to 6 years $($ mean $=1.72 \mathrm{yrs})$ and from 4 months to 4 years (mean $=1.37 \mathrm{yrs}$ ) respectively. The local symptoms found in $\mathrm{BCC}$ were change in color, small ulcer, sometimes itching or bleeding, while in SCC the ones were the appearance of ulcer, bleeding tendency and weight loss in advanced cases. In MM the local symptoms were change in color, i.e. darkening, rapid growth, itching and bleeding. The size of the ulcer or lesion was for
BCC $0.5 \mathrm{~cm}-10 \mathrm{~cm}($ mean $=7.0 \mathrm{~cm})$ for $\mathrm{SCC} 5 \mathrm{~cm}-$ $10 \mathrm{~cm}$ (mean $=7.5 \mathrm{~cm}$ ) while for $\mathrm{MM}$ the lesion was $1 \mathrm{~cm}-5 \mathrm{~cm}($ mean $=3 \mathrm{~cm})$.

The most frequent site of BCC was cheek (29.7\%), followed by nose $(26.4 \%)$ and forehead $(8.8 \%)$. For SCC the most frequent site affected was foot $(21.9$ $\%)$. MM occurred mostly on the plantar pedis (27.3 $\%)$ and foot $(18.2 \%)$. It appeared that in BCC the number of tumors in sun exposed area compared to the non-sun exposed area was 88 versus 3 (96.7\%) while in SCC was 12 versus 20 and in MM was 3 versus 8 , respectively. The ratio of $\mathrm{BCC}$ to $\mathrm{SCC}=2.8: 1$.

\section{DISCUSSION}

Due to the location of Indonesia near the equatorial belt the people will have an extensive sunlight all over the year. Therefore, sun rays will play an important role in producing the skin cancer although the Indonesian has dark skin (mostly skin type V) compared to Caucasian. The majority of Indonesian work in agricultural field and fishery with much exposure of the skin to sunlight.

Basal cell carcinoma (BCC) is the commonest skin cancer in this study. From 139 non-melanoma skin cancer, 91 cases $(65.5 \%)$ were BCC, while SCC was only 32 cases $(23,0 \%)$. The data was similar to the ones found by others.' 10 From the 91 BCC cases there were $53(58.2 \%)$ females and $38(41.8 \%)$ males. This finding was in contrast to other reports ${ }^{10}$ showing that the highest incidence was in males cumpared to females because males were usually outdoor workers.

The controversial findings needs clarifying by considering other factors involved in the occurrence of BCC. As a matter of fact, most of the Indonesian female patients were farmers. The highest tumor incidence was found in the age group between 51-70 years in BCC and between 60-70 years in SCC.

Regarding the distribution of $\mathrm{BCC}, \mathrm{SCC}$ and melanoma according to tumor sites, it appeared that BCC were mostly located on the sun-exposed area, i.e. head $(97.8 \%)$ suggesting the role of sun exposure. Such relationship has been reported elsewhere." 11 The location of SCC were mostly on the non sunexposed area namely $20(62.5 \%)$ or non-sun exposed part and $12(37.5 \%)$ on sun-exposed area. This was also the case with melanoma which had $8(72.7 \%)$ on 
non-sun exposed area, especially on the sole and 3 cases $(27.3 \%)$ on sun exposed area of the body. This suggested that other factors should be taken into account, environmental factor such as trauma or burn. We found only 11 cases of MM (7.9\%) which was very low in comparison with figures found in other populations. $^{10,12,16,17}$

Similarly, we found only 1 case of actinic keratesis (AK) which was very low in comparison with the Japanese findings. ${ }^{17}$ Such difference might depend on the skin type, i.e. the Indonesian people have mostly skin type V while the Japanese have skin type III and mostly skin type II. In addition, melanin pigmentation in human has been considered as the most important biologic protection against ultraviolet radiation ${ }^{\text {18-19 }}$ for preventing both melanoma and non melanoma skin cancer.

Concerning the long duration of the existing tumor and the big size of the lesion, at the time of consultation, it was evident that most of the cases came to the hospital at a very late stage which was accompanied with poor response to the available treatment.

In order to prevent this, we have to organize a comprehensive and intensive educational program to reduce the mortality rate of skin cancer by identifying the cases at earlier stages.

\section{Acknowledgement}

We would like to thank the International Cancer Research Grant system, Monbusho, Japan and the Dean, Faculty of Medicine, University of Indonesia, Jakarta for his approval of the Japan-Indonesia collaborative study. This work has been supported by the grant no. 09042004, under Ministry of Education, Science, Sport and Culture, Government of Japan and was partly supported by the Indonesian Cancer Foundation, the Jakarta International Cancer Conference Fund and the Terry Fox Foundation, Canada. The collaborative study was initiated with Dean's approval no. 845/PT02.H4.FK/E/97. We would also appreciate the Director of Dr. Cipto Mangunkusumo National Central General Hospital for his technical support to finish this work.

\section{REFERENCES}

1. Cornain S, Mangunkusumo R, Nasar IM, Prihartono J. Ten Most Frequent Cancer in Indonesia. Pathology based
Cancer Registry Data of 1988-1992. In: Cancer in Indonesia. National Cancer Registry Center, Jakarta Coordinating Board, 1997.

2. Tjarta A, Kanoko M, Mangunkusumo RR. Malignant Melanoma and Malignant Epidermal Tumors in Jakarta. Relative Frequency and some Histopathological aspects, Presented on 2nd Congress Asia-Pacific Associations Societies of Pathologist, February 20-23, 1991, ManilaPhilippine.

3. Weinstock MA. The epidemic of squamous cell carcinoma. JAMA 1989; 262: 2138-40.

4. Glass AG, Hoover RN. The emerging epidemic of melanoma and squamous cell carcinoma. JAMA 1989; 262: 2097-100.

5. Magnus K. The Nordic profile of skin cancer incidence. A comparative epidemiological study of the three main type of skin cancer. Int J Cancer 1991; 47: 12-9.

6. Marks R, Mc. Charty WH. Skin cancer: increasing incidence and public awareness. Med J Aust 1990; 153: 505-6.

7. Grodstein F, Speizer FE, Hunter DJ. A prospective study of incident squamous cell carcinoma of the skin in the nurses health study. J Natl. Cancer Inst. 1995; 87: 1061-6.

8. Giles G, Marks R, Foley P. Incidence of non-melanocytic skin cancer treated in Australia. Br Med J 1988; 296: 13-7.

9. Kricker A, Armstrong BK, English DR. Sun exposure and non-melanocytic skin cancer. Cancer Cases and Control, 1994; 5: 367-92.

10. Armstrong BK, Holman CD. Malignant melanoma of the skin. Bulletin of WHO 1974; 45: 245-52.

11. Koliias N, Baqer A. Solar middle ultraviolet radiation and skin cancer in Kuwait in BFS. Environmental UV Radiation and Health Effect 1995: 203-9.

12. Autier P. Epidemiology of melanoma. In: Lejeune FJ, Chaudhuri PK, Das Gupta TK (Eds). Malignant Melanoma. Medical and Surgical Management. New York: Mc Graw-Hill Inc., 1994: 1-7

13. International Agency for Research on Cancer. Cancer Incidence in Five Continents. Vol III. IARC Publication No.15. Lyon 1976

14. International Agency for Research on Cancer. Cancer Incidence in Five Continents. Vol V. IARC Publications No. 88. Lyon 1987.

15. Glass $A$ and Hoover $R$. The emerging epidemic of melanoma and squamous cell skin cancer. JAMA 1989; 262: 2097-100.

16. Ichihashi $M$, Ueda $M$, Nagano $T$, Araki K, Ohno $Y$, Cornain S. Clinical and epidemiological study of skin cancer in Japan. Med J Indones 2000, 9:70-6.

17. Suzuki T, Ueda $M$, Naruse $K$, Nagano T, Harada $S$, Imazumi $\mathrm{K}$, et al. Incidence of actinic keratosis of Japanese in Kasai City, Hyogo. J Dermatol Sci 1997; 16: 74-8.

18. Ortonne J-P: Biology and photobiology of the melanin pigmentary system. In: Leujeune FJ, Chaudhuri PK, Das Gupta TK (Eds). Malignant Melanoma. Medical and Surgical Management. New York: Mc Graw- Hill Inc., 1994: 81-9.

19. Tyrell RM. Ultraviolet protection. In: Lejeune FJ, Chaudhuri PK, Das Gupta TK (Eds). Malignant Melanoma. Medical and Surgical Management. New York: Mc Graw- Hill Inc., 1994: 91-5. 